\title{
Microbial Quality Assessment of Commercial Bottled Water Brands in Major Markets in Awka, Nigeria
}

\author{
Onuorah Samuel $^{1, *}$, Nwankwo Florence ${ }^{1}$, Obika Ifeanyi ${ }^{2}$ \\ ${ }^{1}$ Department of Applied Microbiology and Brewing, Nnamdi Azikiwe University Awka, Nigeria \\ ${ }^{2}$ Department of Zoology, Nnamdi Azikiwe University Awka, Nigeria
}

Copyright $(\subset 2016$ by authors, all rights reserved. Authors agree that this article remains permanently open access under the terms of the Creative Commons Attribution License 4.0 International License

\begin{abstract}
The microbial quality of commercial bottled water purchased from Eke-Awka, Ifite-Awka, Amaudo-Awka, Permanent Site-Awka, Amaenyi-Awka, Agu-Awka and Okpuno-Awka Markets, Nigeria were assessed for total bacteria, total fungi, total coliforms and faecal coliforms. The temperature and $\mathrm{PH}$ values were also determined. The total bacteria ranged between 100 and 350 $\mathrm{cfu} / \mathrm{ml}$, total fungi between 10 and $50 \mathrm{cfu} / \mathrm{ml}$, total coliforms from 0 to $30 \mathrm{cfu} / 100 \mathrm{ml}$, faecal coliforms from 0 to 20 $\mathrm{cfu} / 100 \mathrm{ml}$, temperature from $27^{\circ} \mathrm{C}$ to $29^{\circ} \mathrm{C}$, and $\mathrm{PH}$ from 5.7 to 6.3. The microbial isolates from the samples were Pseudomonas aeruginosa, Enterobacter aerogenes, Escherichia coli, Bacillus subtilis, Klebsiella pneumoniae, Penicillium digitatum and Aspergillus niger. Coliforms were not detected from the samples from Eke-Awka and Permanent Site-Awka Markets. The microorganisms were predominant in the samples from Okpuno-Awka Market $(26 \%)$ while they had the least distribution in the samples from Eke-Awka Market (4\%). The predominant bacteria were the gram-negative rods. Escherichia coli was the dominant bacterium (20\%) while Penicillium digitatum was the dominant fungus $(20 \%)$. Most of the samples did not comply with the standard set by regulatory bodies for drinking water and are therefore unsafe for drinking without adequate treatment.
\end{abstract}

Keywords Quality Assessment, Bottled Water, Major Markets, Nigeria

\section{Introduction}

Water can exist as liquid, gas and solid. It occupies about $70 \%$ of the earth's surface and is an essential commodity needed for the survival of humans, animals, plants and microorganisms. However, good and safe drinking water is unavailable to over one billion of the world population [1]. As important as water may be, its economic importance as a medium of transmission of diseases that afflict humans must not be overlooked [2].

Almost two million people every year, the majority of whom are children die from water-related diseases [2] especially from diarrhea which remains the second leading cause of death among children under five years globally. It is estimated that almost one in five child's death is due to diarrhea, surpassing the death caused by AIDS, Malaria and Measles combined [2].

Microbial contamination is the most common reason for water to be deemed unsafe for drinking [1]. It is not possible to test drinking water samples for every water-borne pathogens and detection techniques are often expensive as well as time-consuming [3] and for this reason, indicator organisms are used to test for potential contamination by pathogens. The presence of Escherichia coli is used as an indicator for the presence of water-borne pathogens $[1,4,5]$.

Ground water and surface water are the major sources of drinking water in both urban and rural areas. In Nigeria, ground water contamination is one of the least recognized environmental problems because ground water problems are not readily detected and pathways for contamination are not as noticeable as those affecting surface water [6]. Ground water is recovered from boreholes and deep wells [7] but it is however susceptible to microorganisms that impact human health directly.

Faecal contamination of borehole water occurs when faecal matter from a nearby septic tank infiltrates into the borehole chambers and introduces bacteria and other pathogenic microorganisms into such water drawn from the borehole. Microorganisms that are concerned with water-borne diseases include Salmonella sp, Shigella $s p$, Escherichia coli, Vibrio cholerae [8], Entamoeba histolytica, Giardia lamblia, Balantidium coli, Cryptococcus parvum and Enteroviruses of various clinical ailments which include Poliovirus, Rotavirus, Hepatitis A virus [9,10] and Hepatitis E virus [11].

Awka is the Capital City of Anambra State of Nigeria, with an estimated population of 301, 657 as of 2006 Nigerian census. It is a tropical zone which experiences both dry and wet seasons. The temperature in Awka is generally $27-30^{\circ} \mathrm{C}$ 
between June and December but rises to $32-34^{0} \mathrm{C}$ between January and April. The city has a high demand for potable water though there is little or no government facility for the provision of such water, hence a significant percentage of the population depends on bottled water which sources are borehole waters for their daily water consumption, therefore the objective of this research was to access the microbial quality of commercial bottled water brands in Major Markets in Awka, Nigeria.

\section{Materials and Methods}

\subsection{Study Area}

Awka Town in Anambra State, South-Eastern Nigeria is situated along the highway between Enugu and Onitsha. The Town's industries include printing, publishing, hotels, restaurants and Pharmaceutical firms. Its artisans are famous for wooden and metal crafts. The important commercial products of the area include yams, cassava, maize, palm products, peas, apples and oranges.

\subsection{Sample Collection and Processing}

Twenty one different brands of bottled water ( 3 from each market) were obtained from seven major markets in Awka. The major markets were Eke-Awka, Ifite-Awka, Amaudo-Awka, Permanent Site- Awka, Amaenyi-Awka, Agu-Awka and Okpuno-Awka. They were transported to the microbiology laboratory of Nnamdi Azikiwe University Awka on ice parks for analysis. The microbiological tests were carried out within twenty four hours after collection.

\subsection{The Glass Bottles Sterilization and Media Preparation}

The laboratory glass wares used were sterilized by heating in a hot-air oven at $160^{\circ} \mathrm{C}$ for one hour. The media which were prepared according to the manufacturer's instructions were sterilized by autoclaving at $121^{\circ} \mathrm{C}$ for fifteen minutes. The plates were prepared in duplicates.

\subsection{Total Bacterial Count}

The spread plate technique was employed. 0.1 millilitre of each water brand was spread with a sterile loop on the surface of a sterile nutrient agar (NA). The nutrient agar plates contained Ketoconazole at a concentration of $0.05 \mathrm{mg} / \mathrm{ml}$ added to inhibit fungal growth. Incubation was carried out in an inverted position at $28^{\circ} \mathrm{C}$ for 24 hours after which the bacterial colonies that developed were counted and the result recorded. Each colony was purified by repeated subculturing on nutrient agar plates and stored in sterile nutrient agar slants for characterization and identification

\subsection{Total Fungal Count}

This was carried out using the spread plate method. $0.1 \mathrm{ml}$ of each water sample was dispensed into the centre of a sterile sabouraud dextrose agar (SDA) plate and spread evenly over the agar surface using a sterile glass rod. The agar plate had Chloramphenicol at a concentration of $0.05 \mathrm{mg} / \mathrm{ml}$ to inhibit bacterial growth. Incubation was carried out in an inverted position at $28^{\circ} \mathrm{C}$ for 72 hours after which the fungal colonies that developed were counted and the result recorded. Each colony was subcultured on sterile SDA plates and later stored in sterile SDA slants for characterization and identification.

\subsection{Total Coliform Count}

The membrane filter technique was employed. $100 \mathrm{ml}$ of each sample were passed through a membrane filter and the filter aseptically transferred onto the surface of plates containing MacConkey agar (MA). Incubation was carried out in an inverted position at $28^{\circ} \mathrm{C}$ for 48 hours after which the coliform bacteria that developed were counted and the result recorded. Each colony was subcultured on sterile NA plates and later stored on sterile NA slants for characterization and identification.

\subsection{Faecal Coliform Count}

The membrane filter technique was also used. $100 \mathrm{ml}$ of each water sample was passed through a membrane filter which was thereafter transferred aseptically onto the surface of Eosin methylene blue (EMB) agar contained in plates. Incubation was carried out in an inverted position at $28^{\circ} \mathrm{C}$ for 48 hours after which the coliform bacteria that developed were counted and the result recorded. Each colony was subcultured on sterile NA plates and later stored on sterile NA slants for characterization and identification.

\subsection{Faecal Streptococci Count}

$0.1 \mathrm{ml}$ of each water sample was introduced into test tubes of glucose azide broth and incubated at $45^{\circ} \mathrm{C}$ for 48 hours. The tubes were thereafter examined for acid production which was indicated by a change in the colour of the medium. Acid production is indicative of the presence of faecal Stretococci. The result was further confirmed by introducing $0.1 \mathrm{ml}$ of the samples from the tubes into sterile MacConkey agar and incubating at $45^{\circ} \mathrm{C}$ for 72 hours. Faecal Streptococci produces characteristic minute red colonies on this medium.

\subsection{Clostridium Perfringens Count}

$0.1 \mathrm{ml}$ of each water sample was introduced into sterile 
screw capped bottles containing differential reinforced Clostridial medium. The bottles were then incubated at $37^{\circ} \mathrm{C}$ for 48 hours. A positive reaction is indicated by the blackening of the medium. $0.1 \mathrm{ml}$ of the samples from the tubes was introduced into a tube of litmus milk medium and incubated at $37^{\circ} \mathrm{C}$ for 48 hours to confirm the presence of the organism. A positive reaction is indicated by the production of a stormy clot reaction.

\subsection{Characterization and Identification of the Isolates}

The colonial morphology and biochemical characteristics of the bacterial isolates were determined. Gram staining, Oxidase, Indole, Urease, Catalase, Methyl red, Voges proskaeur, Coagulase, Citrate utilization, Sugar (glucose, sucrose, fructose and galactose) fermentation, Motility and Spore tests were carried out as described by Onuorah et al [12]. The isolates were identified following the scheme of Holt et al [13].

The fungal isolates were characterized and identified on the basis of their colonial and microscopic characteristics. The microscopic characteristics were determined using the lactophenol cotton blue staining and slide culture test, as described by Onuorah et al [14].

\subsubsection{Slide Culture Test}

A fragment of the aerial mycelia was picked with a sterile inoculating needle and inoculated on a slide containing prepared Sabouraud dextrose agar. The slide was thereafter incubated at $28^{\circ} \mathrm{C}$ for 24 hours after which it was stained with lactophenol cotton blue stain, covered with a coverslip and examined under the microscope.

\subsubsection{Lactophenol Cotton Blue Staining}

Two drops of lactophenol cotton blue dye were placed on a clean glass slide after which a fragment of the test fungal culture was teased out into the stain using a sterile straight wire. The slide was then covered with a coverslip, avoiding bubbles, and examined under the microscope. The isolates were identified following the scheme described by Oyeleke and Manga [15].

\subsection{1. $\mathrm{pH}$ and Temperature Determination}

The ${ }_{\mathrm{P}} \mathrm{H}$ values of the samples were taken using $\mathrm{a}_{\mathrm{P}} \mathrm{H}$ meter that was standardized with buffers 4 and $7.100 \mathrm{ml}$ of each sample were introduced into a beaker and the ${ }_{\mathrm{p}} \mathrm{H}$ meter inserted into it. The ${ }_{\mathrm{P}} \mathrm{H}$ values were then read and recorded.

The temperatures of the samples were taken with a thermometer. $100 \mathrm{ml}$ of the sample were introduced into a beaker and the thermometer inserted into it. The temperature was thereafter read and recorded.

\section{Results}

The average temperature and ${ }_{\mathrm{p}} \mathrm{H}$ values of the water samples are shown in Table 1. The temperature ranged between $27^{\circ} \mathrm{C}$ and $29^{\circ} \mathrm{C}$ while the ${ }_{\mathrm{P}} \mathrm{H}$ values were between 5.7 and 6.3 .

Table 1. Average Temperature and ${ }_{\mathrm{pH}} \mathrm{H}$ values of the water samples

\begin{tabular}{|c|c|c|}
\hline Sample Location & Temperature $\left({ }^{\circ} \mathrm{C}\right)$ & ${ }_{\mathrm{pH}}$ \\
\hline Eke-Awka & 29 & 6.3 \\
\hline Ifite-Awka & 28 & 5.7 \\
\hline Amaudo-Awka & 29 & 6.2 \\
\hline Permanent Site-Awka & 29 & 6.2 \\
\hline Amaenyi-Awka & 28 & 5.7 \\
\hline Agu-Awka & 28 & 6.2 \\
\hline Okpuno-Awka & 27 & 6.3 \\
\hline
\end{tabular}

The average microbial counts of the water samples are presented in Table 2. The total bacterial counts were between $100 \mathrm{cfu} / \mathrm{ml}$ and $350 \mathrm{cfu} / \mathrm{ml}$, the total fungal counts between $10 \mathrm{cfu} / \mathrm{ml}$ and $50 \mathrm{cfu} / \mathrm{ml}$, total coliform counts between 0 $\mathrm{cfu} / 100 \mathrm{ml}$ and $30 \mathrm{cfu} / 100 \mathrm{ml}$ while the faecal coliform counts ranged between $0 \mathrm{cfu} / 100 \mathrm{ml}$ and $20 \mathrm{cfu} / 100 \mathrm{ml}$.

Table 2. Average Microbial Counts of the Water Samples

\begin{tabular}{|c|c|c|c|c|}
\hline Sample & $\begin{array}{c}\text { Total } \\
\text { Bacterial } \\
\text { Counts } \\
\text { (cfu/ml) }\end{array}$ & $\begin{array}{c}\text { Total } \\
\text { Fungal } \\
\text { Counts } \\
\text { (cfu/ml) }\end{array}$ & $\begin{array}{c}\text { Total } \\
\text { Coliform } \\
\text { Count } \\
\text { (cfu/100ml) }\end{array}$ & $\begin{array}{c}\text { Faecal } \\
\text { Coliform } \\
\text { Counts } \\
\text { (cfu/100ml) }\end{array}$ \\
\hline Eke-Awka & 100 & 10 & 0 & 0 \\
\hline Ifite-Awka & 283 & 42 & 25 & 10 \\
\hline Amaudo-Awka & 230 & 31 & 22 & 12 \\
\hline $\begin{array}{c}\text { Permanent Site- } \\
\text { Awka }\end{array}$ & 115 & 15 & 0 & 0 \\
\hline Amaenyi-Awka & 312 & 45 & 10 & 4 \\
\hline Agu-Awka & 260 & 37 & 15 & 6 \\
\hline Okpuno-Awka & 350 & 50 & 30 & 20 \\
\hline
\end{tabular}

The microbial isolates in the water samples are shown in Table 3. They were Pseudomonas aeruginosa, Enterobacter aerogenes, Escherichia coli, Bacillus subtilis, Klebsiella pneumoniae, Penicillium digitatum and Aspergillus niger.

Table 3. Microbial Isolates in the Water Samples

\begin{tabular}{|c|c|}
\hline Bacteria & Fungi \\
\hline Pseudomonas aeruginosa & Penicillium digitatum \\
\hline Enterobacter aerogenes & Aspergillus niger \\
\hline Escherichia coli & \\
\hline Bacillus subtilis & \\
\hline Klebsiella pneumoniae & \\
\hline
\end{tabular}

The frequency of occurrence of the microbial isolates in the major markets is presented in Table 4. They were predominant in the samples from Okpuno-Awka Market (26\%), while the distribution was lowest in the samples from Eke-Awka Market (4\%). 
Table 4. Frequency of occurrence of the Microbial Isolates in the Major Markets

\begin{tabular}{|c|c|c|c|c|c|c|c|c|c|}
\hline Sample & $\begin{array}{c}\text { Pseudomonas } \\
\text { aeruginosa } \\
(n)\end{array}$ & $\begin{array}{c}\text { Enterobacter } \\
\text { aerogenes } \\
(n)\end{array}$ & $\begin{array}{c}\text { Escherichia } \\
\text { coli } \\
(n)\end{array}$ & $\begin{array}{c}\text { Bacillus } \\
\text { subtilis } \\
(n)\end{array}$ & $\begin{array}{c}\text { Klebsiella } \\
\text { pneumoniae } \\
(n)\end{array}$ & $\begin{array}{c}\text { Penicillium } \\
\text { digitatum } \\
(n)\end{array}$ & $\begin{array}{c}\text { Aspergillus } \\
\text { niger } \\
(n)\end{array}$ & $\begin{array}{c}\text { Total } \\
\text { occurrence }\end{array}$ \\
\hline Eke Awka & 1 & 0 & 0 & 0 & 0 & 1 & 0 & 2 & 4 \\
\hline Ifite Awka & 0 & 2 & 2 & 1 & 0 & 0 & 2 & 7 & 14 \\
\hline $\begin{array}{c}\text { Amaudo } \\
\text { Awka }\end{array}$ & 0 & 1 & 1 & 1 & 2 & 2 & 0 & 7 & 14 \\
\hline $\begin{array}{c}\text { Permanent } \\
\text { Site Awka }\end{array}$ & 0 & 0 & 0 & 2 & 0 & 1 & 3 & 6 & 12 \\
\hline $\begin{array}{c}\text { Amaenyi } \\
\text { Awka }\end{array}$ & 0 & 1 & 2 & 0 & 1 & 3 & 0 & 7 & 14 \\
\hline Agu Awka & 3 & 1 & 1 & 1 & 0 & 1 & 1 & 8 & 16 \\
\hline $\begin{array}{c}\text { Okpuno } \\
\text { Awka }\end{array}$ & 4 & 2 & 4 & 0 & 0 & 2 & 1 & 13 & 26 \\
\hline Total & $8(16)$ & $7(14 \%)$ & $10(20 \%)$ & $5(10)$ & $3(6 \%)$ & $10(20 \%)$ & $7(14 \%)$ & 50 & 100 \\
\hline
\end{tabular}

$\mathrm{n}=$ number of Isolates

\section{Discussion}

The average temperature and ${ }_{\mathrm{P}} \mathrm{H}$ values of the samples were between $27^{\circ} \mathrm{C}$ and $29^{\circ} \mathrm{C}$ and 5.7-6.3 respectively (Table 1). The average temperatures were within the mesophilic range and were suitable for the growth of heterotrophic organisms in the water samples. The temperature values conformed to the World Health Organization Standard for drinking water $\left(25^{\circ} \mathrm{C}-40^{\circ} \mathrm{C}\right)$. The temperature of any water body affects the rate of proliferation of microorganisms [16]. The water samples were slightly acidic and hence supported the growth of microorganisms. The ${ }_{\mathrm{P}} \mathrm{H}$ values were however below the WHO and Standard Organization of Nigeria guidelines for drinking water (6.5-8.5). Eniola et al [17] however, reported a ${ }_{\mathrm{P}} \mathrm{H}$ range of 5.4-7.0 for borehole water samples stored indoor and outdoor in containers of different colours.

Bacteria and fungi were isolated from all the samples assessed (Table 2). Coliforms which are indicators of water quality were detected in all but the samples from Eke-Awka and Permanent Site Markets. Most of the water samples did not comply with the WHO [1] and SON [18] guidelines for drinking water since they contained the total coliform and faecal coliform bacteria in excess of the maximum permitted limits of $10 \mathrm{cfu} / 100 \mathrm{ml}$ and $0 \mathrm{cfu} / 100 \mathrm{ml}$ respectively. Their $\mathrm{pH}$ values were also higher than the recommended range of 6.5-8.5 [1,18].

The organisms isolated from the samples were Pseudomonas aeruginosa, Enterobacter aerogenes, Escherichia coli, Bacillus subtilis, Klebsiella pneumoniae Penicillium digitatum and Aspergillus niger (Table 3). This result agreed with Birmingham et al [8], VanDerslice and Briscoe [19] and Wright et al [20] who reported the presence of coliforms in the water samples they studied. The dominant bacteria were the gram-negative rods while Bacillus subtilis was the only gram-positive bacterium isolated. Yeasts were not isolated from the samples. In addition, Escherichia coli was the dominant bacterium while Penicillium digitatum was the dominant fungus in the samples.
Microorganisms were predominant in the samples from Okpuno-Awka Market while the samples from Eke-Awka Market contained the lowest number of microorganisms (Table 4). This variation may be attributed to the packaging material, sanitary condition of the bottling environment, source of water supply and the hygiene status of the bottling staff.

Escherichia coli and Penicillium digitatum were predominant in the water samples while Klebsiella pneumoniae had the lowest frequency of occurrence (Table 4). Escherichia coli is commonly found in the lower intestines of warm-blooded organisms. Faecal-oral transmission is the major route through which pathogenic strains of this bacterium cause diseases. Though most Escherichia coli strains do not cause diseases, the virulence strain can cause gastroenteritis, urinary tract infections and neonatal meningitis. When $E$. coli is present in a water sample, other microorganisms can also be present.

Water that has coliforms or Escherichia coli is not safe for drinking $[1,18]$. The presence of faecal coliforms in the water samples assessed is an indication of recent faecal pollution which suggests access to undesirable materials and could constitute a potential health hazard to the consumers. Enterobacter aerogenes, also a coliform bacterium is commonly found in polluted water, manure and soil. It's presence in some of the samples assessed may pose a public health risk.

Pseudomonas aeruginosa has been reported to be an opportunistic human and plant pathogens as well as a soil bacterium. Its ability to thrive under harsh conditions may have contributed to its being wide spread in nature. Pseudomonas infection is a particular problem in the environment as it is a nosocomial infection. Klebsiella pneumoniae is a human pathogen and can cause several diseases of man.

Although Bacillus subtilis is commonly found in soil, it is a normal gut commensal in humans. It can survive extreme temperature to which it is exposed as a result of its heat resistant spores. Penicillium digitatum and Aspergillus niger 
are ubiquitous soil fungi present wherever organic material is available. They are also present in the air. Aspergillus species cause Aspergillosis with symptoms which include fever, chest pain and cough. Faecal Streptococci and Clostridium perfringens were not isolated from the samples indicating that the pollution of the water was of recent occurrence.

The result of this assessment showed that the microbial quality of most of the commercial bottled water sampled as well as their $\mathrm{pH}$ values were above the limit recommended by the World Health Organization and Standards Organization of Nigeria, therefore they must be adequately treated before bottling in hygienic environments. Filtration through sand bed filters, Chlorination and Ozonation are recommended.

\section{Conclusions}

The pollution of water bodies by microorganisms has become a major global problem because of the increase in water-borne diseases with the attendant high cost of water treatment. Since commercial bottled water is in high demand in Awka, there is urgent need to improve its quality. Proper treatment of the water samples before bottling, bottling in a hygienic environment as well as adequate post-bottling handling are recommended.

\section{REFERENCES}

[1] World Health Organization. Guidelines for Drinking-Water Quality. $3^{\text {rd }}$ edition, WHO Press, Geneva, Switzerland, Pp 398, 2006.

[2] World Health Organization. Global Water Supply and Sanitation Assessment Report. WHO, Geneva, Switzerland, Pp 110, 2000.

[3] W.O.K. Grawbow. Water-borne diseases: Update on water quality assessment and control. Water SA Vol. 22, No. 2, 193-202, 1996. http://www.researchgate.net/publication 1279547110 .

[4] E.I. Chukwura. Aquatic Microbiology. Otawa Press Limited Nkpor, Onitsha. Pp44-61, 2001.

[5] G.C. Okpokwasili, T.C. Akujiobi. Bacteriological indicators of tropical water quality. Environmental and Toxicological Water Quality, Vol.11, No.2, 77-81, 1996. doi: 10.1002/(sici)1098-2256 (1996) 11:2<77::AID-TOXI>3.0.C $\mathrm{O} ; 2-5$.

[6] I. Adekunle, M.T. Adetunji, A.M. Gbadebo, O.P. Banjoko. Assessment of Ground Water Quality in a Typical Rural Settlement in Southwest Nigeria. International Journal of Environmental Research and Public Health, Vol. 4, No.4, 307-318, 2007. DOI: 10.3390/ijerph 200704040007.

[7] I.N. Onwughara, V. I.E. Ajiwe, H.O. Nnabuenyi. Elemental Seasonal assessment of borehole waters in Umuahia North Local Government Area in Abia State, Nigeria. International
Journal of Science Innovations and Discoveries, Vol.3, No.3, 336-347, 2013. www. ijsidonline.info.

[8] M.E. Birmingham, L.A. Lee, N. Ndayimirije, S. Nkurikiye, B.S. Hersh, J.G. Wells, M.S. Deming. Epidemic Cholera in Burundi: Patterns of transmission in the Great Rift Valley Lake Region. Lancet, Vol. 349, No. 9057, 981-985. 1997. http://www.ncbi.nlm.nih.gov/pubmed/9100624.

[9] T.G. Metcalf, J.L. Melnick, M.K. Estes. Environmental Virology: from detection of virus in sewage and water by isolation to identification by molecular biology - a trip of over 50 years. Annual Review in Microbiology, Vol. 49, 461-487, 1995. http://www.ncbi.nlm.nih.gov/pubmed/8561468.

[10] V.C. Rao, J.L. Melnick. Monitoring for Viruses in Wastewater and Water. Environmental Virology, Vol. 1, 18-40, 1986. DOI:1007/978-1-4615-9761-2_3.

[11] S. Benjelloun, B. Bahbouhi, N. Bouchrit, L. Cherkaoui, N. Hda, J. Mahjour, A. Benslimane. Seroepidemiological study of an acute Hepatitis E outbreak in Morocco. Research in Virology, Vol. 148, No. 4, 279-287, 1997. http://www.sciencedirect.com/science/article/pii/S09232516 97883653.

[12] Onuorah Samuel, Obika Ifeanyi, Odibo Frederick, Orji Michael. An Assessment of the Bacteriological Quality of Tsire-Suya (Grilled Beef) sold in Awka, Nigeria. American Journal of Life Science Researches, Vol.3, No.4, 287-292, 2015. www.worldofresearches.com.

[13] J.G. Holt, N.R. Krieg, P.H.A. Sneath, T.W. Staley. Bergey's Manual of Determinative Bacteriology, $9^{\text {th }}$ ed. Williams and Wilkins, New York, U.S.A. Pp. 817-825, 1994.

[14] Onuorah Samuel, Obika Ifeanyi, Okafor Ugochukwu. Filamentous Fungi Associated with the Spoilage of Post-harvest Sweet Orange Fruits (Citrus sinensis) sold in Awka Major Markets, Nigeria. Bioengineering and Bioscience, vol. 3, No.3, 44-49, 2015. DOI:10.13189/bb.2015.030303.

[15] S.B. Oyeleke, S.B. Manga. Essentials of Laboratory Practice in Microbiology. Tobest Publishers, Minna, Nigeria. Pp.36-75, 2008.

[16] M.J. Pelczar, E.C.S. Chan, R.K.C. Noel. Microbiology ( $15^{\text {th }}$ ed $)$ Tata McGraw Hill, New Delhi, Pp 571, 2005.

[17] K.I.T. Eniola, D.Y. Obafemi, S.F. Awe, I.I. Yusuf, O.A. Falaiye, A.O. Olowe. Effects of containers and storage conditions on bacteriological quality of borehole water. Nature and Science of Sleep, Vol.5, No.4, 1-6, 2007. http://www.researchgate.net/publication/261798351.

[18] Standards Organization of Nigeria. Nigerian Standard for Drinking Water Quality, NIS 554, 15-19, 2007.

[19] J. VanDerslice, J. Briscoe. All coliforms are not created equal-a comparison of the effects of water source and in-house water contamination on infantile diarrheal disease. Water Resources Research, Vol. 29, No.7, 1983-1995, 1993. DOI: 10.1029/92WR02994.

[20] J. Wright, S. Gundry, R. Conroy. Household drinking water in developing countries: a systematic review of microbiological contamination between source and point-of-use. Tropical Medicine and International Health, Vol.9, No. 1, 106-117, 2004. DOI:10.1046/j.1365-3156.2003.01160.x 